\title{
The association of donor vasoactive drugs with pancreas transplant graft survival
}

Link to publication record in Manchester Research Explorer

\section{Citation for published version (APA):}

Shapey, I., Summers, A., Yiannoullou, P., Augustine, T., Rutter, M., \& Van Dellen, D. (2017). The association of donor vasoactive drugs with pancreas transplant graft survival. Poster session presented at British Transplantation Society Annual Congress, Harrogate, United Kingdom.

\section{Citing this paper}

Please note that where the full-text provided on Manchester Research Explorer is the Author Accepted Manuscript or Proof version this may differ from the final Published version. If citing, it is advised that you check and use the publisher's definitive version.

\section{General rights}

Copyright and moral rights for the publications made accessible in the Research Explorer are retained by the authors and/or other copyright owners and it is a condition of accessing publications that users recognise and abide by the legal requirements associated with these rights.

\section{Takedown policy}

If you believe that this document breaches copyright please refer to the University of Manchester's Takedown Procedures [http://man.ac.uk/04Y6Bo] or contact uml.scholarlycommunications@manchester.ac.uk providing relevant details, so we can investigate your claim.

\section{OPEN ACCESS}




\title{
The association of donor vasoactive drugs with pancreas transplant graft survival
}

\author{
IM Shapey, A Summers, P Yianoullou, T Augustine, MK Rutter, D van Dellen \\ Department of Renal and Pancreatic Transplantation, Manchester Royal Infirmary \\ Manchester, United Kingdom
}

\section{Introduction}

- Vasoactive drugs $(\mathrm{VaD})$ are commonly used to correct abnormal haemodynamics of organ donors in Intensive Care Units (ICU).

- VaDs can differentially affect insulin secretion positively (dobutamine) or negatively (noradrenaline).

\section{Aim}

- We hypothesised that some VaDs might induce beta-cell stress/death and be associated with adverse pancreas transplant outcomes.

- We aimed to assess relationships of VaD use to pancreas transplant graft survival.

\section{Methods}

- We used Cox-regression in UK Transplant registry data (2004-2016) to assess associations between use of five VaDs and covariate-adjusted pancreas graft survival (median follow-up: 3 years) before and after correction for multiple testing ( $p$-value threshold: $<0.01$ ).

\section{Results}

- In 2271 pancreas transplant donors, VaDs were used in the following numbers (proportions): dobutamine 80 (3.5\%), dopamine 87 (3.8\%), adrenaline $167(7.4 \%)$, noradrenaline 1657 (73.0\%) and vasopressin $1273(56.1 \%)$.

- Use of adrenaline, dopamine and vasopressin were not related to graft survival.

\section{Noradrenaline use vs non-use}

Noradrenaline use was associated with better graft survival after adjusting for:

- Donor variables HR - $(95 \% \mathrm{Cl}): 1.35$ (1.10-1.66) $\mathrm{p}=0.004$

- Donor and recipient variables - HR $(95 \% \mathrm{Cl}): 1.35$ (1.05-1.72), $\mathrm{p}=0.018$

- Donor and recipient variables and cold ischaemic time - HR (95\% Cl): 1.30

(1.003-1.67), $p=0.048$; (but not after correction for multiple testing)

- (Cox-regression analysis)

\section{Dobutamine use vs non-use}

Dobutamine use was associated with poorer graft survival after adjusting for:

- Donor variables HR $(95 \% \mathrm{Cl})$ : $0.65(0.43-0.98) \mathrm{p}=0.039$;

- But this relationship became non-significant after further adjustment for recipient variables and cold ischaemic time.

- (Cox-regression analysis)

Figure 1: Donor-recipient-CIT

Figure 2: Donor adjusted survival adjusted survival (days) according to (days) according to donor donor noradrenaline use vs non-use dobutamine use vs non-use
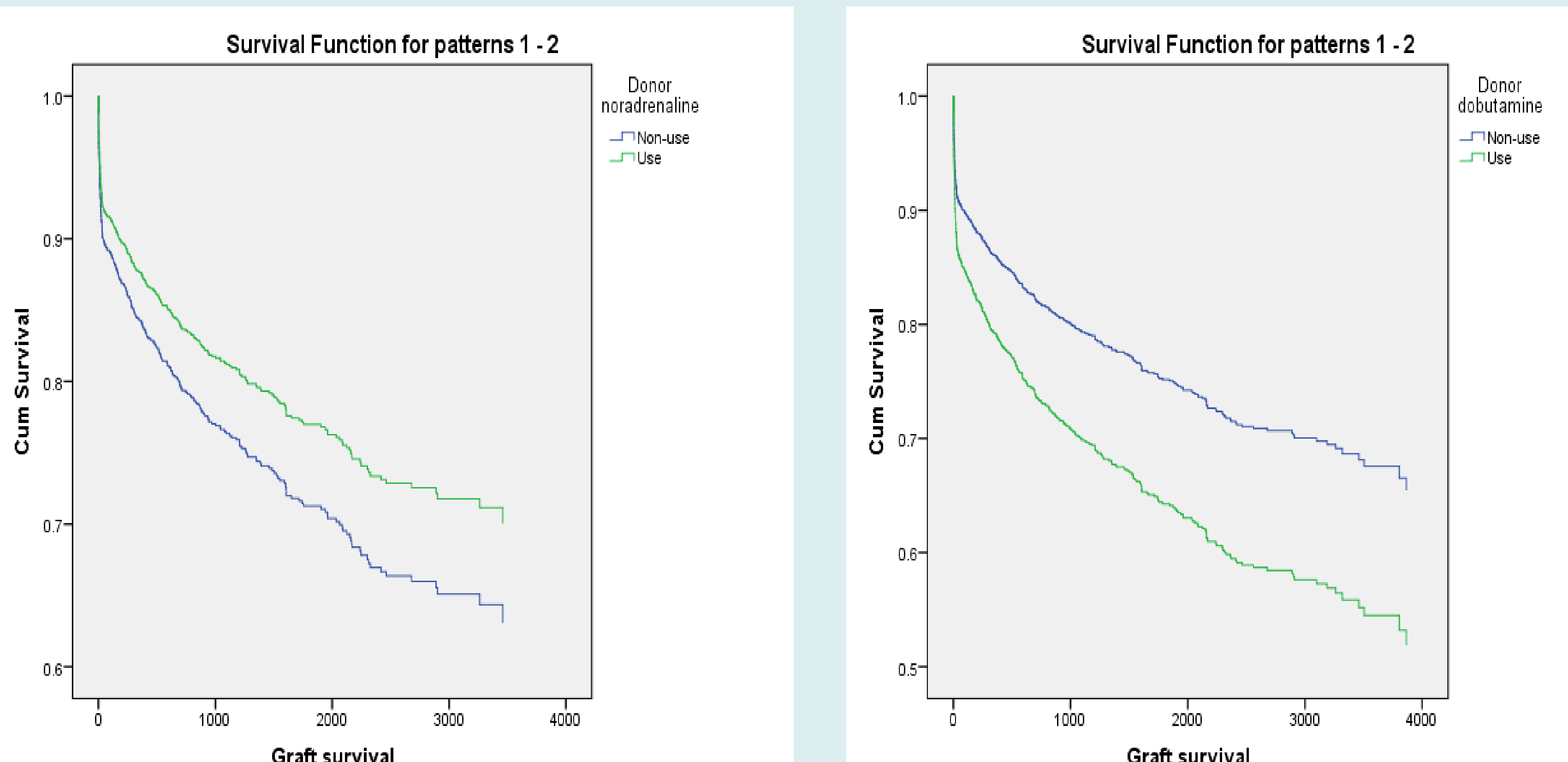

Table 1: Donor variables associated with noradrenaline use in intensive care

Donor noradrenaline use in
intensive care
No $(n=614) \quad$ Yes $(n=1657)$

p-value

Donor variables

Age

Sex (male)

35.61 (SD 13.68) 34.51 (SD 13.38)

$293(47.7 \%) \quad 845(51.0 \%)$

Ethnicity

White

Asian

Black

Other

BMI

Smoking

Alcohol excess

Past hypertension

Past cardiac disease

Cardiac arrest

Creatinine

Amylase

Peri-retrieval hypotension

Donor Type (DBD)

Cause of death

Trauma

Meningitis

Stroke (thrombo-embolic)

Intracranial haemorrhage

Hypoxic brain damage

Brain tumour

Other
$576(95.7 \%)$

$5(0.8 \%)$

$3(0.5 \%)$

$18(3.0 \%)$

23.51 (SD3.50)

$304(50.0 \%)$

$53(9.4 \%)$

$69(11.3 \%)$

$25(4.4 \%)$

$195(32.1 \%)$

76.24 (SD 42.35)

81.53 (SD 171.75)

$333(58.4 \%)$

$451(73.5 \%)$

$82(13.4 \%)$

$15(2.4 \%)$

$36(5.9 \%)$

$296(48.2 \%)$

$140(22.8 \%)$

$13(2.1 \%)$

$32(5.2 \%)$ (univariate)

1523 (93.3\%)

$37(2.3 \%)$

$27(1.7 \%)$

$46(2.8 \%)$

23.617 (SD 3.60)

$830(50.8 \%)$

$113(8.4 \%)$

$125(7.6 \%)$

$41(2.7 \%)$

$479(29.2 \%)$

$83.49(50.02)$

7.16 (SD 195.76)

$1082(67.2 \%)$

$1427(86.1 \%)$

$292(17.6 \%)$

$39(2.4 \%)$

$88(5.3 \%)$

$843(50.9 \%)$

$281(17.0 \%)$

$22(1.3 \%)$

91 (5.5\%)

\section{Conclusions}

- Noradrenaline use was associated with better graft survival in models adjusting for donor and recipient variables but not after correcting for multiple testing.

- Further research is required to replicate these findings and establish whether relationships are truly significant and causal before any change in practice is made.

- Better outcomes associated with noradrenaline use could be explained by inhibition of pancreatic insulin secretion thereby resting beta-cells at a time of high metabolic stress. 